\title{
Differences of Microflora Depending on the Parts of Human Stool
}

\author{
Chong Jin Park, ${ }^{1}$ Jin-Ki Baek, ${ }^{1}$ Hyun-Soo LeE, ${ }^{1}$ Yasuhito Tashiro ${ }^{2}$ \\ and Tomotari MrTsuOKA ${ }^{3}$ \\ 'Sun Hill Research Lab., Sam Yang Group RED Center, 63-2, Hwaam-Dong, \\ Yusung-Gu, Taejeon 305-348, Korea, \\ ${ }^{2}$ Bio Science Laboratories, Meiji Seika Kaisha, Ltd., 5-3-1, Chiyoda, Sakado, Saitama 350-02 and \\ ${ }^{3}$ Nippon Veterinary and Animal Science University, 2-27-5, Sakai, Musashino, Tokyo 180
}

(Received for publication, June 14, 1995)

\begin{abstract}
Distribution of the fecal microflora in several specimens from different locations of the human stool was analyzed with the steel wool method and the plate-in-bottle method. Total bacterial counts and the number of bacteroidaceae at the upper portion of the stool were significantly higher than those at the lower portion by both culture methods. Lecithinase-negative clostridia were recovered in significantly higher numbers at the middle or upper portion compared with the lower portion by the plate-in-bottle method. The number of lactobacilli was significantly higher at the upper portion than at the other portions. There was no significant difference in the numbers of other bacterial groups observed. The percentage of bifidobacteria in the total bacterial populations enumerated by the steel wool method varied among the three portions of the stool, while those counted by the plate-in-bottle method were consistent. These results indicate that the composition of the fecal microflora was differently analyzed at the parts of the stool possibly because of oxygen diffused from the anus. A culture method for highly oxygen sensitive anaerobes could minimize this difference.
\end{abstract}

Key words: human fecal microflora; stool; difference; distribution

The distribution of microflora in the human alimentary tract has been investigated by various researchers $(3,5)$ and understood as follows: The microflora in the small intestine is relatively simple. Lactobacilli, aerobic streptococci and veillonellae are mainly found there. However, the microflora in the colon is very complex and bacterial counts reach $10^{11} / \mathrm{g}$ in the rectum. Anaerobic bacteria such as bacteroidaceae, eubacteria, peptococcaceae, clostridia and bifidobacteria are predominantly detected in the lower intestine. Fecal flora is supposed to be similar to the colonic microflora, thus stool specimen is routinely chosen for the investigation on large intestinal flora. Nevertheless, the microflora in different locations of the excreted stool have not been examined so far.

The number of anaerobes in the alimentary tract or the stool is affected by culture 
methods that are taken for primary isolation of the organisms. Since Hungate (4) developed the anaerobic roll tube method for the isolation of cellulolytic bacteria from the rumen in 1950, Drasar (2) and Aranki et al. (1) made strict anaerobic room and developed the anaerobic glove box method. And Mitsuoka et al. originated a simple and sure plate-in-bottle method by which extremely oxygen sensitive bacteria could be isolated and cultured, and the human fecal bacteria could be examined up to $10^{11} / \mathrm{g}$ (7). These methods commonly employed pre-reduced media and all procedures from the collection of the specimen to the inoculation of diluted sample were performed under anaerobic conditions.

In the present study, we examined the distribution of microflora in the stool by comparing two culture methods providing different degrees of anaerobiosis, which will provide useful technical information when researchers investigate the fecal microflora.

\section{MATERIALS AND METHODS}

Specimen. In this experiment, fecal samples were supplied from a man aged 29 years, weighing $63 \mathrm{~kg}$ and who lived for three months in Japan. He came from South Korea. During the experiment, he consumed an ordinary Japanese style diet.

Sampling of stool for the study. Stool samples were collected six times on different days. Sampling was performed as follows: a plastic sheet was spread on the ground of a toilet and stool was excreted into a sterile bowl placed on the plastic sheet to avoid contamination. Each fragment of the stool was connected in a sequential order of defecation. Samples were taken from the connected stool at locations of 0-2, 11-15 and $28-30 \mathrm{~cm}$ from the tip of the stool. Collected samples were thoroughly mixed in a plastic bag filled with oxygen-free $\mathrm{CO}_{2}$ gas and one gram of each sample was immediately transferred to $9 \mathrm{ml}$ of pre-reduced diluent $(8)$. The test tube containing a stool sample was sealed with a butyric rubber stopper under the stream of oxygen-free $\mathrm{CO}_{2}$ gas and stored at $4^{\circ} \mathrm{C}$ until tested.

Investigation of fecal microflora. Fecal solution was diluted with the same pre-reduced anaerobic diluent under the stream of oxygen-free $\mathrm{CO}_{2}$ gas and a series of 10 -fold dilutions $\left(10^{-1}\right.$ to $\left.10^{-8}\right)$ was made in a test tube with a butyric rubber stopper. A 0.05 $\mathrm{ml}$ aliquot of dilutions was inoculated on 4 non-selective media (M10, EG, BL and TS agar plates) and 10 selective media (BS, NBGT, ES, NN, VS, LBS, TATAC, DHL, PEES and $\mathrm{P}$ agar plates) prepared according to a previous paper (8). Culture on M10 medium was carried out by the plate-in-bottle method $(7)$ at $37^{\circ} \mathrm{C}$ for 5 days. Other media for anaerobes were incubated at $37^{\circ} \mathrm{C}$ in an anaerobic jar filled with $\mathrm{CO}_{2}$ gas with a steel wool coated with a reduced form of copper (steel wool method) (10) for 23 days. Aerobes were cultured in the air at $37^{\circ} \mathrm{C}$ for $1-2$ days.

Identification of isolates. Colonies from all agar plates were observed with a microscope after Gram staining. Identification of all isolates were performed according to the manual of Mitsuoka (8) based on colonial and cellular morphology. 
Table 1. Stool samples and culture methods in the experiment

\begin{tabular}{|c|c|c|c|c|c|c|}
\hline & \multicolumn{6}{|c|}{ Sampling time } \\
\hline & $1 \mathrm{st}$ & 2nd & $3 \mathrm{rd}$ & 4 th & 5 th & 6 th \\
\hline Length $(\mathrm{cm})$ & 11 & 29 & 28 & 34 & 45 & 55 \\
\hline Weight (g) & 29 & 120 & 108 & 118 & 147 & 185 \\
\hline No. of fragments & 2 & 1 & 2 & 3 & 4 & 4 \\
\hline Sampling location ${ }^{\mathrm{a}}$ & $\mathbf{L}, \mathbf{M}$ & $\mathrm{L}, \mathrm{M}, \mathrm{U}$ & $\mathrm{L}, \mathrm{M}, \mathrm{U}$ & $\mathrm{L}, \mathrm{M}, \mathrm{U}$ & $\mathrm{L}, \mathrm{M}, \mathrm{U}$ & $\mathrm{L}, \mathrm{M}^{\mathrm{b}}, \mathrm{U}$ \\
\hline Culture method ${ }^{\mathrm{c}}$ & $\mathbf{S}, \mathbf{P}$ & $\mathrm{S}, \mathrm{P}$ & $\mathrm{S}, \mathrm{P}$ & $\mathrm{S}$ & $\mathrm{S}, \mathrm{P}$ & $\mathrm{S}, \mathrm{P}$ \\
\hline
\end{tabular}

${ }^{\mathrm{a}} \mathrm{L}$ : lower portion $(0-2 \mathrm{~cm}$ from the tip) of the stool, $\mathrm{M}$ : middle portion $(11-15 \mathrm{~cm}$ from the tip) of the stool, U: upper portion $(28-30 \mathrm{~cm}$ from the tip) of the stool.

${ }^{b}$ Only the steel wool method was employed for this sample.

${ }^{\mathrm{c}} \mathrm{S}$ : the steel wool method, P: the plate-in-bottle method.

RESULTS

\section{Characteristics of Sampled Stools}

During the experiment, the subject had no diarrheal or constipated stool. Characteristics of the sampled stool are shown in Table 1. Except for the first sampling, we were able to collect total length of 29 to $45 \mathrm{~cm}$ stools. Total length $(\mathrm{cm}) /$ weight $(\mathrm{g})$ of the stools ranged from 3.3 to 4.1 except for the first sample (2.6) because of its short length consisting of larger proportion of thin tip of the stool compared with other stools.

\section{Fecal Microflora at Different Locations}

When the steel wool method was used, total bacterial counts and the number of bacteroidaceae were significantly higher at the upper portion of the stool compared with the lower portion (Table 2). The number of lactobacilli at the upper portion was also significantly higher than those at the other two portions. There was no significant difference in the numbers of other bacteria. However bacterial counts at the upper portion of the stool showed the tendency to be greater than those observed at the lower portion except for the number of enterobacteriaceae. The mean percentage of bifidobacteria in the total bacterial populations decreased from the lower to upper portion of the stool.

The numbers of predominant anaerobes enumerated by the plate-in-bottle method are represented in Table 3. Total bacterial counts and the number of bacteroidaceae were also significantly higher at the upper portion of the stool than the lower portion by this culture method. Lecithinase-negative clostridia were significantly higher in number at the upper portion compared with the other two portions of the stool. The mean percentage of bifidobacteria in the total counts was apparently similar at any portions.

Comparison of the Culture Methods for the Investigation of the Fecal Microflora

We incubated diluted stool by the two methods, providing different degrees of 
Table 2. Composition of fecal microflora at different parts of the stool by the steel wool method

\begin{tabular}{|c|c|c|c|c|c|c|}
\hline \multirow[b]{2}{*}{ Organism } & \multicolumn{3}{|c|}{ Distance from distal end of stool ${ }^{\mathrm{a}}$} & \multicolumn{3}{|c|}{ Significant difference ${ }^{b}$} \\
\hline & $\begin{array}{l}\text { Lower } \\
\text { (L) }\end{array}$ & $\begin{array}{l}\text { Middle } \\
\text { (M) }\end{array}$ & $\begin{array}{l}\text { Upper } \\
\text { (U) }\end{array}$ & $\mathrm{L}: \mathrm{M}$ & $\mathrm{L}: \mathrm{U}$ & $\mathbf{M}: \mathrm{U}$ \\
\hline Total bactcria & $10.6 \pm 0.2^{\mathrm{c}}(6 / 6)^{\mathrm{d}}$ & $10.7 \pm 0.2(6 / 6)$ & $10.9 \pm 0.2(5 / 5)$ & & ** & \\
\hline \multicolumn{7}{|l|}{ Anaerobes } \\
\hline Bacteroidaceae & $9.8 \pm 0.4(6 / 6)$ & $10.2 \pm 0.3(6 / 6)$ & $10.5 \pm 0.2(5 / 5)$ & & $* *$ & \\
\hline Eubacteria & $10.0 \pm 0.2(6 / 6)$ & $10.1 \pm 0.3(6 / 6)$ & $10.2 \pm 0.1(5 / 5)$ & & & \\
\hline Peptococcaceae & $9.5 \pm 0.4(4 / 6)$ & $9.6 \pm 0.4(6 / 6)$ & $10.0 \pm 0.2(5 / 5)$ & & & \\
\hline Bifidobacteria & $10.0 \pm 0.2(6 / 6)$ & $10.1 \pm 0.3(6 / 6)$ & $10.2 \pm 0.1(5 / 5)$ & & & \\
\hline & $\begin{array}{c}(31 \%)^{e} \\
42+17(3 / 6)\end{array}$ & $(26 \%)$ & $(20 \%)$ & & & \\
\hline $\begin{array}{l}\text { Lecithinase-positive } \\
\text { clostridia }\end{array}$ & $4.2 \pm 1.7(3 / 6)$ & $5.0 \pm 1.0(2 / 6)$ & $5.0 \pm 0.3(2 / 5)$ & & & \\
\hline $\begin{array}{l}\text { Lecithinase-negative } \\
\text { clostridia }\end{array}$ & $9.0 \pm 0.6(5 / 6)$ & $9.5 \pm 0.3(6 / 6)$ & $9.5 \pm 0.5(5 / 5)$ & & & \\
\hline Lactobacilli & $7.0 \pm 0.3(6 / 6)$ & $7.2 \pm 0.2(6 / 6)$ & $7.6 \pm 0.2(5 / 5)$ & & $* *$ & * \\
\hline \multicolumn{7}{|l|}{ Aerobes } \\
\hline Enterobacteriaceae & $8.5 \pm 0.5(6 / 6)$ & $7.9 \pm 0.5(6 / 6)$ & $8.2 \pm 0.6(5 / 5)$ & & & \\
\hline Streptococci & $6.9 \pm 0.6(6 / 6)$ & $7.2 \pm 0.7(6 / 6)$ & $7.6 \pm 0.4(5 / 5)$ & & & \\
\hline
\end{tabular}

${ }^{\mathrm{a}}$ Sec the footnote of Table 1.

${ }^{b}$ Data were analyzed statistically by Student's $t$-test; * $p<0.05,{ }^{* *} p<0.01$.

${ }^{c}$ Mean \pm S.D. of log bacterial counts/g stool (when present).

${ }^{d}$ Frequency of occurrence (No. of samples detected/No. of samples tested).

'Mean percentage in the total bacterial populations.

Table 3. Composition of fecal microflora at different parts of the stool by the plate-in-bottle method

\begin{tabular}{|c|c|c|c|c|c|}
\hline \multirow[b]{2}{*}{ Organism } & \multicolumn{3}{|c|}{ Distance from distal end of stool ${ }^{\mathrm{a}}$} & \multicolumn{2}{|c|}{ Significant difference $^{b}$} \\
\hline & $\begin{array}{l}\text { Lower } \\
\text { (L) }\end{array}$ & $\begin{array}{l}\text { Middle } \\
\text { (M) }\end{array}$ & $\begin{array}{l}\text { Upper } \\
\text { (U) }\end{array}$ & $\mathrm{L}: \mathrm{M}$ & $\mathrm{L}: \mathrm{U} \mathbf{M}: \mathbf{U}$ \\
\hline Total bacteria & $10.8 \pm 0.2^{c}(5 / 5)^{d}$ & $11.0 \pm 0.2(4 / 4)$ & $11.0 \pm 0.1(4 / 4)$ & & * \\
\hline Bacteroidaceae & $10.4 \pm 0.2(5 / 5)$ & $10.4 \pm 0.3(4 / 4)$ & $10.7 \pm 0.2(4 / 4)$ & & $*$ \\
\hline Eubacteria & $10.1 \pm 0.2(5 / 5)$ & $10.2 \pm 0.0(4 / 4)$ & $10.2 \pm 0.1(4 / 4)$ & & \\
\hline Peptococcaceae & $10.0 \pm 0.3(5 / 5)$ & $10.2 \pm 0.2(4 / 4)$ & $10.2 \pm 0.2(4 / 4)$ & & \\
\hline Bifidobacteria & $\begin{array}{c}10.0 \pm 0.2(5 / 5) \\
(17 \%)^{\mathrm{e}}\end{array}$ & $\begin{array}{c}10.2 \pm 0.3(4 / 4) \\
(17 \%)\end{array}$ & $\begin{array}{c}10.3 \pm 0.3(4 / 4) \\
(17 \%)\end{array}$ & & \\
\hline $\begin{array}{l}\text { Lecithinase-negative } \\
\text { clostridia }\end{array}$ & $9.6 \pm 0.3(5 / 5)$ & $10.2 \pm 0.2(4 / 4)$ & $10.1 \pm 0.1(4 / 4)$ & * & $* *$ \\
\hline
\end{tabular}

${ }^{a}$ See the footnote of Table 1.

${ }^{\mathrm{b}}$ Data were analyzed statistically by Student's $t$-test; ${ }^{*} p<0.05,{ }^{* *} p<0.01$.

'Mean \pm S.D. of log bacterial counts/g stool (when present).

${ }^{\mathrm{d}}$ Frequency of occurrence (No. of samples detected/No. of samples tested).

${ }^{\mathrm{e}}$ Mean percentage in the total bacterial populations.

anaerobiosis. When we compared the two culture methods, significantly higher average numbers were observed in the total counts and the number of bacteroidaceae at the lower portion of the stool by the plate-in-bottle method than by the steel wool 
method. The numbers of peptococcaceae and lecithinase-negative clostridia at the middle portion were also greater by the plate-in-bottle method. There was no significant difference in the numbers of bifidobacteria and eubacteria. In one or two samples from the lower portion of the stool, peptococcaceae and/or lecithinase-negative clostridia were not detected on the plates cultured by the steel wool method.

\section{DISCUSSION}

Although this study was performed with the specimens from only a single subject, useful information was obtained. In the present study, we compared bacterial numbers at different parts of the stool. Some anaerobic groups of bacteria highly recovered from the upper portion of the stool were greater in number by using the plate-in-bottle method for fastidious anaerobes than by the steel wool method. The results suggest that oxygen diffused from the anus affects the viability of the anaerobes in the stool. When the intestinal microflora is estimated precisely by analyzing the fecal flora, it is advisable to collect stool samples after eliminating the lower portion which would be affected by oxygen.

Mitsuoka (5) has reported bacterial flora in the alimentary tract in humans. He observed that lactobacilli and aerobic streptococci were predominant in the ileum together with bifidobacteria. In the colon, lactobacilli and streptococci slightly increased from the ileum to the cecum and decreased from the cecum to the rectum, whereas bifidobacteria greatly increased in the cecum and remained predominant in the rectum. In our study, the number of lactobacilli was significantly higher at the upper portion of the stool than at the middle portion. The number of streptococci also showed a similar trend from the lower to upper portion of the stool. Therefore, changes in the number of lactic acid bacteria in the present study were similar to those observed in the hind alimentary tract by Mitsuoka. The slight decrease of lactobacilli and streptococci from the rectum to the stool might be due to the factors concerning survival of these organisms such as attachment to the mucus layer or the epithelial colonic cells, decrease in free water and bacterial competition for the nutrients.

It was reported that heterogeneity of bacterial flora was observed between the periphery and the core of the colonic contents in rats (13). To our knowledge, no data are available as for such a regional heterogeneity in the human colonic flora. Our preliminary examination showed that there was no difference in the bacterial flora between the periphery and the core of the stool (data not shown). Therefore, stool sample is supposed to be a homogeneous mixture of the lumen contents and the mucus layer, and does not reflect the regional heterogeneity of the colonic microflora between the periphery and the core of the lumen.

Since many people pay attention to the usefulness of bifidobacteria, researchers often use the percentage of bifidobacteria in the total bacterial populations as an indicator of healthiness in the gut (9). This is because it has reported that a decrease in the populations of bifidobacteria was found in some gut-related disorders $(9,11,12)$. In the data presented here, the percentage of bifidobacteria in the total bacterial popula- 
tions was more affected by the location of the stool sample when the steel wool method was employed. The main reason for this may be that other predominant fastidious anaerobes at the lower part of the stool exposed to oxygen diffused from the anus were killed and decreased during isolation procedures. With the plate-in-bottle method, such a decrease could be minimized and a relatively consistent balance of the microflora was measured at all sites of the stool collected. Therefore, in order to obtain a reliable value for the percentage of not only bifidobacteria but also other predominant bacteria, it is recommended to use culture methods for highly oxygen-sensitive anaerobes such as the plate-in-bottle method. From our results, the best prediction of colonic microflora could be achieved by sampling the upper portion of the stool and using culture methods giving strict anaerobiosis.

Acknowledgements. The authors gratefully acknowledge the critical advice of Mikiro Imamura of Nikken Chemicals Co., Ltd.

\section{REFERENCES}

(I) Aranki, A., S.A. Syed, E.B. Kenney, and R. Freter. 1969. Isolation of anacrobic bacteria from human gingiva and mouse cecum by means of a simplificd glove box procedure. Appl. Microbiol. 17: $568-576$.

(2) Drasar, B.S. 1967. Cultivation of anacrobic intestinal bacteria. J. Pathol. Bacteriol. 94: 417-427.

(3) Gorbach, S.L., A.G. Plaut, L. Nahas, L. Weinstein, G. Spanknebel, and R. Levitan. 1967. Studies of intestinal microflora II. Microorganisms of the small intestine and their relations to oral and faecal flora. Gastroenterology 53: 856-867.

(4) Hungate, R.E. 1950. The anaerobic mesophilic cellulolytic bacteria. Bacteriol. Rev. 14: 1-49.

(5) Mitsuoka, T. 1974. Recent advances in the research on the intestinal flora with special references to the anacrobic flora. Jpn. J. Bacteriol. 29: 773-788.

(6) Mitsuoka, T., T. Sega, and S. Yamamoto. 1965. Eine verbesserte Methodik der qualitativen und quantitativen Analyse der Darmflora von Menschen und Tieren. Zentralbl. Bakteriol. Parasitenkd. Infektionskr. Hyg. Abt. Orig. A195: 455-469.

(7) Mitsuoka, T., Y. Morishita, A. Terada, and S. Yamamoto. 1969. A simplc method ('plate-in-bottle method') for the cultivation of fastidious anacrobes. Jpn. J. Microbiol. 13: 383-385.

(8) Mitsuoka, T. (ed.). 1984. A color atlas of intestinal bacteria, Shobunsha Press, Tokyo (in Japanese).

(9) Mutai, M., and R. Tanaka. 1987. Ecology of Bifidobacterium in the human intestinal flora. Bifidobacteria Microflora 6: 33-41.

(10) Parker, C.A. 1955. Anaerobiosis with iron wool. Aust. J. Exp. Biol. Med. Sci. 33: 33-37.

(11) Shimoyama, T., S. Hori, K. Tamura, M. Yamamura, M. Tanaka, and K. Yamazaki. 1984. Microflora of patients with stool abnormality. Bifidobacteria Microflora 3: 35-42.

(12) Wagenfeld, K. 1991. Occurrence of bifidobacteria in the stool of multiple sclerosis patients. Zentralbl. Bakteriol. 275: 541-548.

(13) Watanabe, T., T. Yajima, and T. Sakata. 1989. Regional heterogeneity of bacteria and their glycosidase activities across and along the colonic segments of rats. Lett. Appl. Microbiol. 8: 29-31. 